\title{
熱可塑性高分子材料の疲労強度に及的す 温度の影響
}

\author{
工業技術院㵶維高分子材料研究所 中野詔 彦 - 長谷川澄子
}

\section{EFFECT OF TEMPERATURE ON THE FATIGUE STRENGTH OF SOME THERMOPLASTIC POLYMERS}

\author{
By Nobuhiko Nakano and Sumiko Hasegawa
}

(Research Institute for Polymers and Textiles, 1-1-4 Yatabe-higashi, Tsukuba, Ibaraki, 305 Japan)

The fatigue strength in thermoplastic polymers is affected remarkably by temperature. The effects of temperature on the fatigue strength of some thermoplastic polymers such as poly(methyl methacrylate) (PMMA), polyoxymethylene (POM), polyethylene (PE), poly(vinyl chloride) (PVC), polystyrene (PS) and acrylonitrile-butadiene-styrene copolymer (ABS) have been investigated with the change of rise of surface temperature by the fatigue, alternating stress amplitude-number of cycles $(\mathrm{S}-\mathrm{N})$ curves and tensile stress-strain $(\mathrm{S}-\mathrm{S})$ curves.

The change of fatigue strength of thermoplastic polymers with temperature may be indicated with one curve which has a certain transition temperature and the fatigue fracture in thermoplastic polymers may be roughly divided into three types as thermal fracture which breaks with the rise of temperature, cracking fracture which does not depend on the rise of temperature and the mixed fracture. PMMA is thermal fracture-type, ABS and PS are cracking fracture-type and POM, PE and PVC are the mixed fracture-type at $-20^{\circ} \mathrm{C} \sim 60^{\circ} \mathrm{C}$.

(Received October 14, 1985)

\section{1. 緒言}

熱可蓋珄高分子材料の疲労強度は温度の影響在大い儿 受けるので，ヒステリシス損失による材料の温度上昇の 影響も大きい上思われる。高分子材料の波学に関す石研

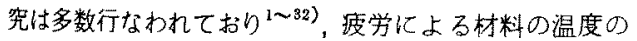
上昇についてはすでに 1944 年にLazanら ${ }^{33)}$ が韩告して いる。またShimamura $ら^{84,35)}$ は試験片表面の温度变化 を連続测定し，繰り返し応力一繰り返し数曲線( $\mathrm{S}-\mathrm{N}$ 曲 線)の転移点と温度上界の関係について考察している。 最近の研究は応力，振動数，試料のディメンション及ひ 熱伝導特性，環境温度及び材料特性の影響が重要である ことを指摘している゙ ${ }^{30 \sim 90)}$ 。Schmidt ら ${ }^{40)}$ は, 熱発生量 が材料のダンピング及び応力振幅の平方に比例し，動的 弹性率に反比例して增加するとよを示し，Ratnerら
は材料の温度上昇が上記の因子に加えて，振動数，試料 の值径に比例し熱伝導率に反比例するととを示した。 Ferry ${ }^{4 !}$ ，線形粘弾性の仮定加類似の関係を見い 出し，材料の温度変化は振動数，提失コンブライアンス 及び応力搰䒇の平方に比例し，密度及び比熱に反比例す るととを示している。Riddell ら ${ }^{97,38)}$ は材料の温度上昇 及びそれに基つく熱破壇について検討し温度上昇が損失 コンプライアンスの変化に密接な関係があり，ガラス転 移点 $\left(T_{g}\right)$ 付近に抽て急激に温度上昇が起ることを示 し，熱破壊は疲学条件により応力上の共同作用で材料があ る限界温度に到達したときに生ずること走した。Sauer $b^{12,20,21)}$ は，行子量, 枕力及び振動数の増大とと6に温 度上昇幅が增大するととを示した。分子量上疲労強度の 関係については多くの研究がなされている,

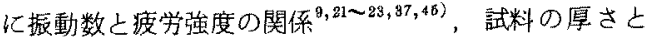


疲労强度 0 関係 $^{10,36,87)}$, 振動波形亡疲労強度 0 関倸 ${ }^{36,42)}$, 疲労試験の中断之疲学強度 関係 $^{87,43 \sim 45)}$, 等温非等温

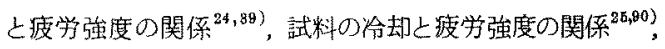

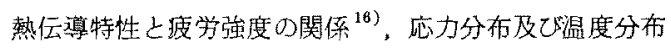
上疲労強度の関係 ${ }^{10)}$ ，などが検討され，いずれの場合に

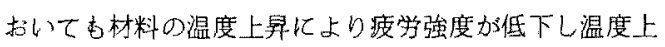
昇を阻上することに上り疲学强度が上界するととが示さ れた。Crawford ら ${ }^{42)}$ は，熱破罱は振動数に依存するか子，

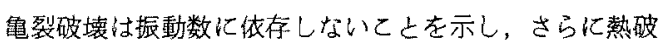
罗在生じない服界の振動数，応力及び形状の実験的な関 係老見い出した。疲労象裂の進展挙動に関する研究は多

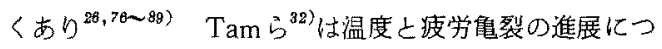
いて応力㹡大係数と龟裂進展の関係加ら分類している。 またChen $ら^{6.11)}$ は，クレーズ発生上疲学抵抗の関係に つて述べている。一般に疲労强度は温度の增加とし6 に減少することが示されている゙ が, Dillon ${ }^{73)}$ は疲労寿 命のサイクル数の対数か絶対温度に比例して減少するこ と老示した。大石 ${ }^{74}$ 及びBedmoreら ${ }^{75)}$ は，材料のS N曲線之機械的性質の関係を示し，Oikawa ${ }^{7)}$ は，睘境 温度の変化による $\mathrm{S}-\mathrm{N}$ 曲線の变化加らフェノール系高 分子複合材料につて，くり返し応力上疲労破塄までの くり返し数の関係を見い出している。上述の多くの研究 結果仙，以下の事実の重要性を示している。すな元， 熱可塑性高分子材料に拟いは疲労破壊加睡裂破壊と熱 破壊に分類され条件に上り異なるが雨破填の転移点が存 在し，最古重要な条件は環境温度及ひ疲学に上る試料の 温度上昇などの温度条件である。またてれらの変化上密 接な関係にあるのが痋学のS一N曲線であり，材料の特 性である。

本報告で，熱可塑性高分子材料の疲労現象における 種々の変化を明らかにするために, 試料形状及び振動数 が一定の試験条件に抢りる熱可塑性高分子材料の繰り返 し届曲疲労試験化基つく疲学强度に及ぼす温度の影響を 波労による温度上昇の幅の変化, 瑥度上昇のタイプ：S 一N曲線のタイプ及び引張試験における応力一ひずみ曲 線(S-S曲線) のタイプの変化なよ゙の面から検討した結 果を述へる。

\section{2. 実}

試料としては，ポリオキシメチレン(POM，ジュラコ ソ)、ポリメチルメタクリレート(PMMA，アクリライ トS)，アクリロニトリルーブタジェンースチレン共重 合体(ABS, サイコラックGS-E), ポリ塩化ビニル(PVC, Geon $103 \mathrm{EP}-8)$, ポリエチレン( $\mathrm{PE}$, 三井石油化学) 及びポリスチレン(PS，デンカスチロールNW-1-301) の6 種類の市販シート(厚さ3 mm)を用いた。
波労試験機は，ASTM-B型荷重一定型繰り返し屈曲 疲労試験機を使用した。振動数は $25 \mathrm{~Hz}$ であった。上記 シートからASTMB型試験片を切り出した。温度は試 験機に恒温槽をとりつけて変化させ， $-20^{\circ} \mathrm{C}, 0^{\circ} \mathrm{C}, 20$ ${ }^{\circ} \mathrm{C} ， 40^{\circ} \mathrm{C} 及 ひ ゙ 60^{\circ} \mathrm{C}$ 等温雾囲気中で夷験を行なった。張 試験忏インストロンを用い，温度の調整は同試驗機に恒 温槽を組み込み雲囲気中で実験を行っだ。引張試験片は 1 号試験片（JIS K 6301）之同寸法のものを用いた。源学 試験片の表面温度の測定は，熱電対型の温度計のセンサ 一部尔を接着テープで試料表面に固定し, 疲労試娩の開 始加ら速続的に測定した。センサーの固定の疲学強度への 影響ははとんどなかった。なお温度測定には，参考よし て赤外線放射顕微鏡(バーンズK.K.) も一部使用したが， 熱電対による测定結果とほぼ阙様の結果老得た。

\section{3. 結果}

\section{$3.1 \mathrm{~S}$-N曲線に及ぼす温度の影響}

冈1〜6は，各試料の繰り返し応力一繰り返し数曲線 ( S-N曲線)の鼬度による変化を示したものである。図 1 はPMMAのー20 C 60 $\mathrm{C}$ における $\mathrm{S}-\mathrm{N}$ 曲線で, 各

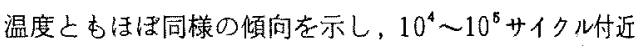
に届折点を有している。温度の增加に対しては, $10^{7} サ$ イクルの疲学強度がほぼ直線的に低下している。図2 估

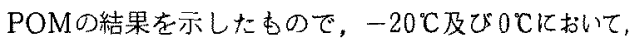
$\mathrm{S}-\mathrm{N}$ 曲線に転移点が古らわれており，疲労破壊の機構 が異なるととを示唆している。図 3 はPEの結果であり - $20^{\circ} \mathrm{C} の \mathrm{~S}-\mathrm{N}$ 曲線に颃いて $10^{6}$ サイクル付近化転移点 があらわれている。図 4 はPVCの結果であり，40Cに おけるS-N曲線佂転移点があらわれている。図5估PS の結果であり，各盜度と屯S一N曲線は類似の下に凸の 傾向を示しており, 温度に上る $10^{7}$ 疲労强度の変化岋大 きくない。図6はABSの結果であり，各温度におりる $\mathrm{S}$-N曲線は類似の倾问示しており，107波労强度は $-20^{\circ} \mathrm{C} \sim 20^{\circ} \mathrm{C}$ 及び $40^{\circ} \mathrm{C} \sim 60^{\circ} \mathrm{C}$ 変化は小さく, $200^{\circ}$ と 40 C の相違が大である。

\section{2 疲労強度に及ぼす温度の影響}

以上の結果加ら、107+イクルにおける波労強度の温 度に対する変化を各試料须いて求的る上园70ように なる。全ての材料はNielsen ${ }^{2)}$ が述へているように温度 の増加に対して疲労强度が低下する倾向を示すか，その 温度に対する低下の傾问は材料によって簧なる。各材料 はDillon ${ }^{79}$ が述へているような統一的な傾向は示さない。 またフょノール系高分子笪合材料について Oikawa ${ }^{7)}$ 示しているような直線的な低下は, 全試料では起らない。 PMMAは温度の增大に対して疲学強度は直線的低下 している。POMは，低温から20Cまでの疲労強度の低 


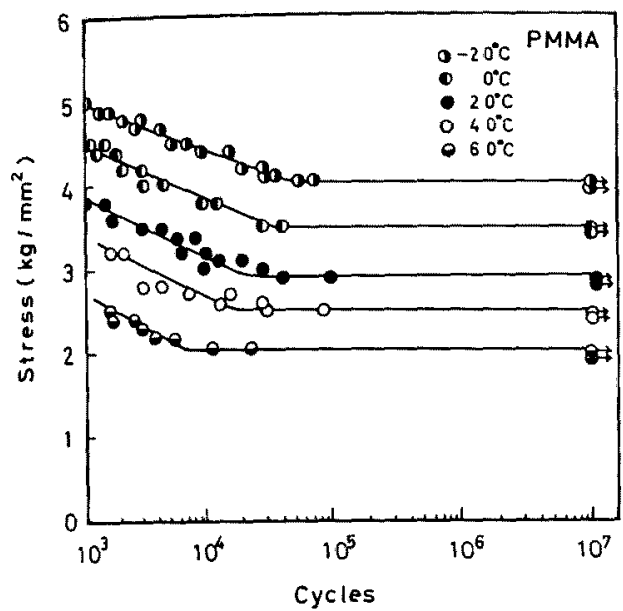

Fig. $1 \mathrm{~S}-\mathrm{N}$ curves of PMMA at $-20^{\circ} \mathrm{C} \sim 60^{\circ} \mathrm{C}$.

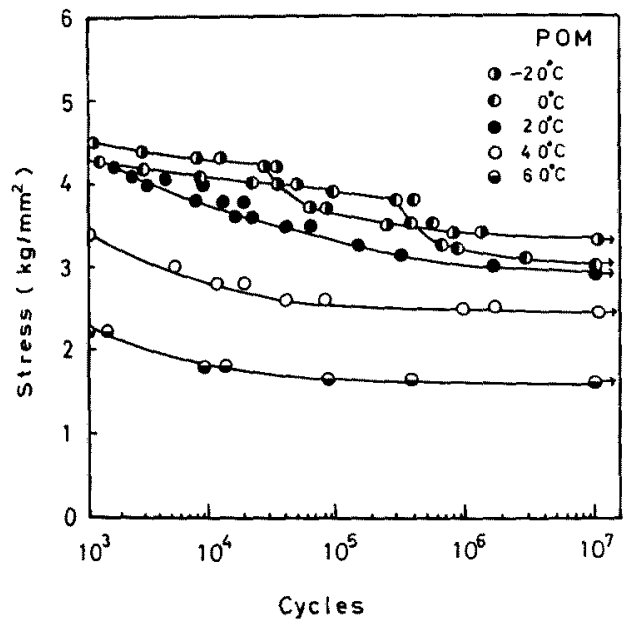

Fig. $2 \mathrm{~S}-\mathrm{N}$ curves of $\mathrm{POM}$ at $-20^{\circ} \mathrm{C} \sim 60^{\circ} \mathrm{C}$.

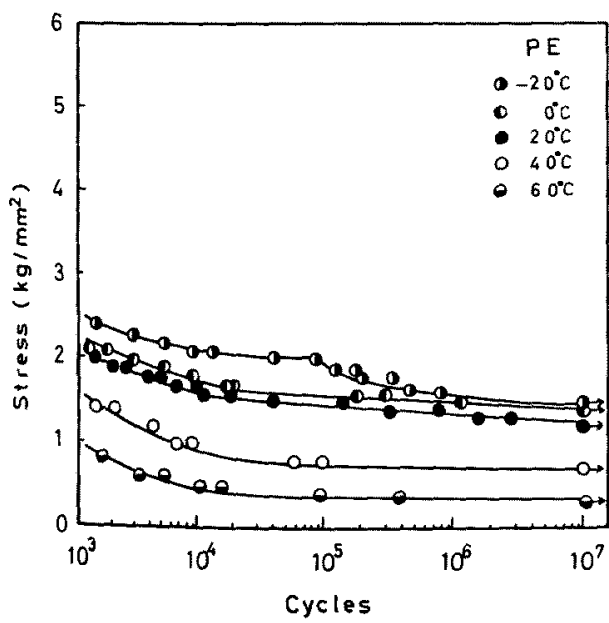

Fig. $3 \mathrm{~S}-\mathrm{N}$ curves of $\mathrm{PE}$ at $-20^{\circ} \mathrm{C} \sim 60^{\circ} \mathrm{C}$.

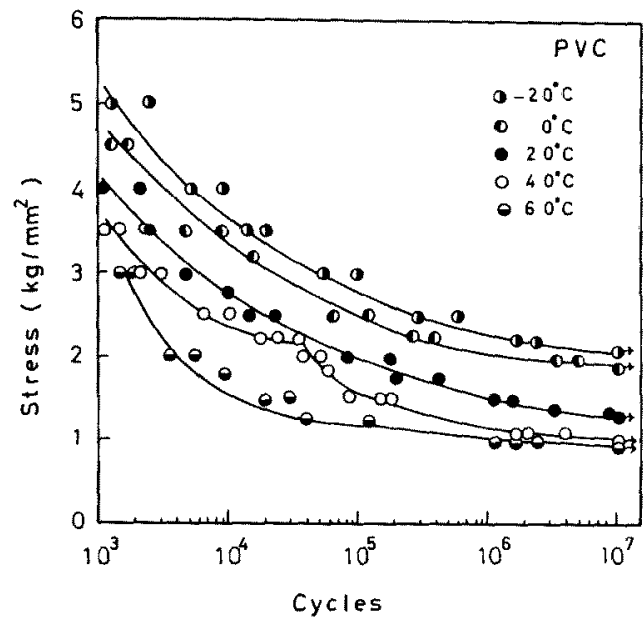

Fig. $4 \mathrm{~S}-\mathrm{N}$ curves of PVC at $-20^{\circ} \mathrm{C} \sim 60^{\circ} \mathrm{C}$.

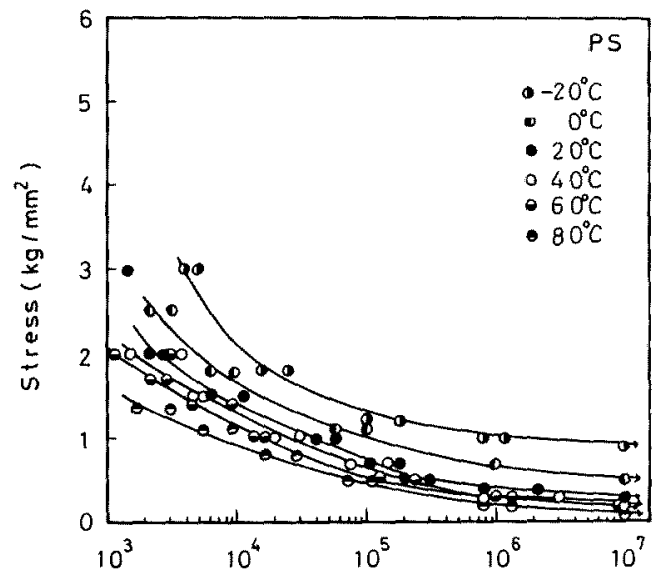

Cycles

Fig. $5 \mathrm{~S}-\mathrm{N}$ curves of PS at $-20^{\circ} \mathrm{C}-60^{\circ} \mathrm{C}$.

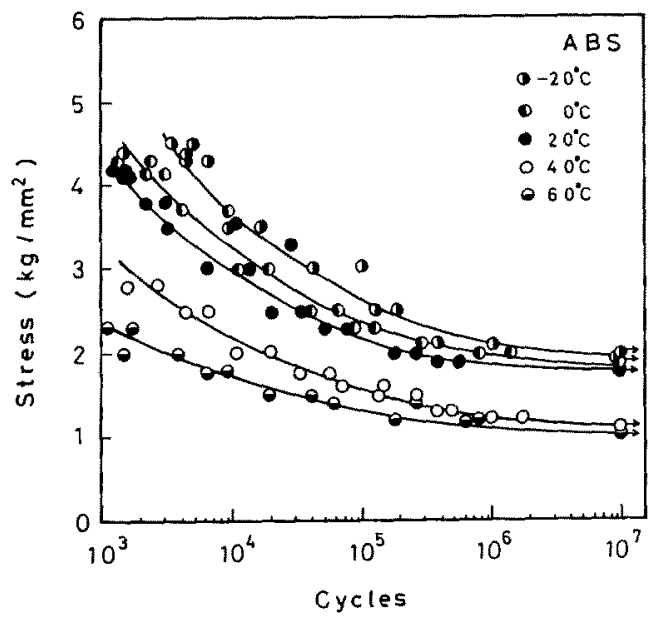

Fig. $6 \mathrm{~S}-\mathrm{N}$ curves of $\mathrm{ABS}$ at $-20^{\circ} \mathrm{C} \sim 60^{\circ} \mathrm{C}$. 


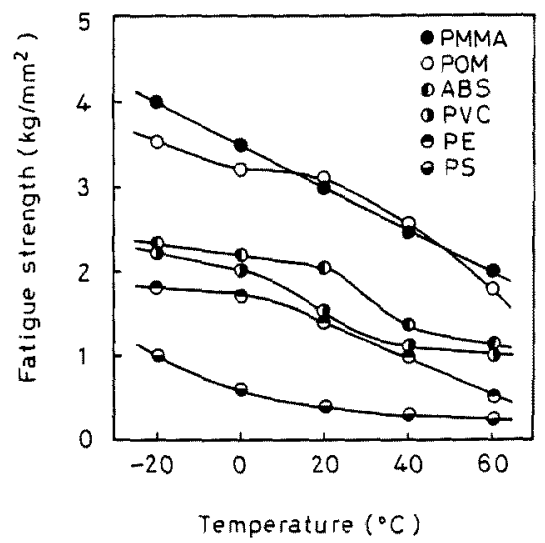

Fig. 7 Relation between temperature and fatigue strength of thermoplastic polymers.

下が䌅やかて，その後温度が高くなるに従い疫労強度が 急激低下する纾向を示す。PEも0 $\mathrm{C}$ までは疲労強度 の低下は㗔や加であるが，その後温度の增加之上李に急 激に低下している。PVC及びABSは温度の増加に対し て跛学強度はS字曲線を描いて低下している。PSは湿 度の增大に対して疲学強度が漸減している。

\section{3 疲労による表面温度の変化}

$S-N$ 曲楾及び疲学強度の变化に及ばす温度の影響の 上述の上うな結果の考察に資するために，繰り返し応力 振幅に基つくくヒステリシス損失による温度上界の変化を 試片の表面温度の变化から測定した。疲労試験片の表面 温度の測定は前述のように，志力，振勳数及び試験片の 形状などの影響の面からPMMA，ポリカーボネート。 PS，PVC，ABS，ポリアミドなどの測定結果が報告

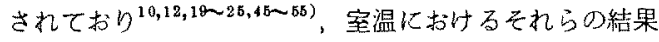
は，本実験の結果之ほ活同様の傾何を示している。6 イロンについては零国気温度に上る温度上昇の変化につ

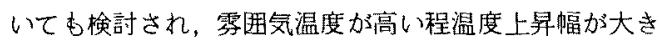

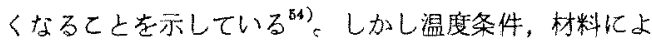
って仿以下に示すように必ずしあ雾肃気温度加高い程温 度上鼠幅が大きくなると限らない。図8１3亿各試料 の疲労による表面温度上昇の傾向をサイクル数に対して 示した。この場合は振動数か $25 \mathrm{~Hz}$ と一定であり，材料 の形状む一定なので，材料の種類，応力及び雾田気瀑度 の影響が検討できる。図8はPMMAの結果を示したも ので，応力振偪が大きい場合すなわち疫労破壊のサイク ル数が小さい場合には，㵋度上昇が小さいうちに破壤す るか， $10^{4}$ 付近加ら一定温度に到達すると破壊する傾问 を示す。温度上昇幅は $20^{\circ} \mathrm{C}$ ○きが最大でそれより尚温 度加高くなっても低くなっても温度上舁幅は低下する傾

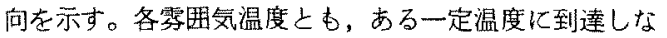

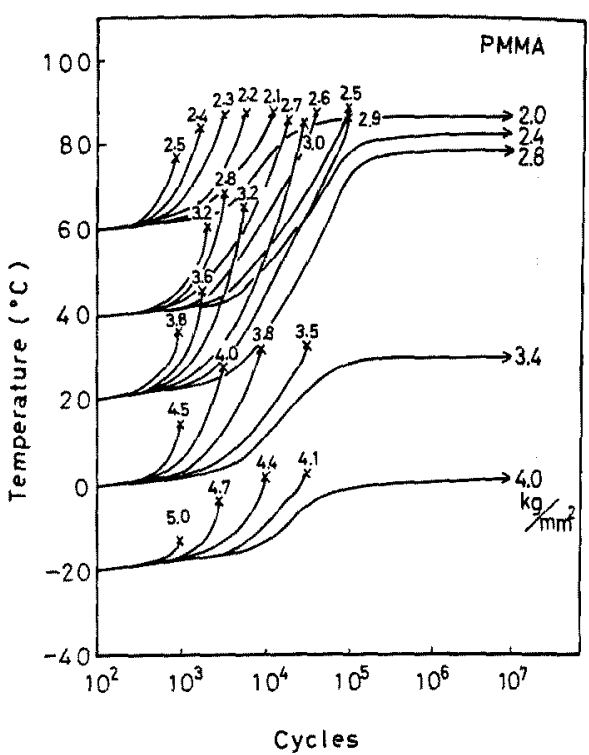

Fig. 8 Rise of surface temperature by fatigue at various temperatures for PMMA.

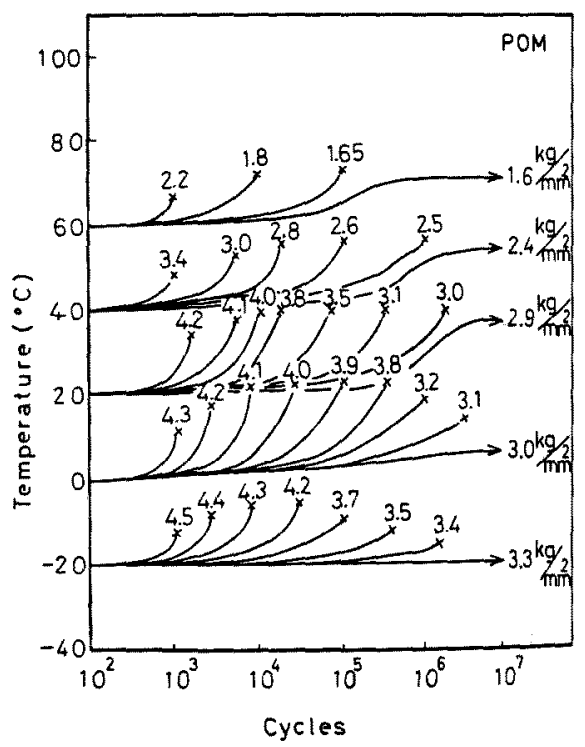

Fig. 9 Rise of surface temperature by fatigue at various temperatures for POM.

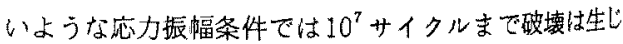
ない。また $20^{\circ} \mathrm{C}$ 上の雾囲気温度では，破填が材料の $T_{\mathrm{g}}\left(80^{\circ} \mathrm{C}\right)$ に依存していることを示している。図9は POMKついての温度上昇傾问であり，20C〜60 C 籍 囲で佉，PMMA亡同様にある一定鼠度侄到達すると度 労破填するのに対し，0更及びー20Cではサイク山数加 大きくなると破填までの温度上其幅が低下する傾向字 


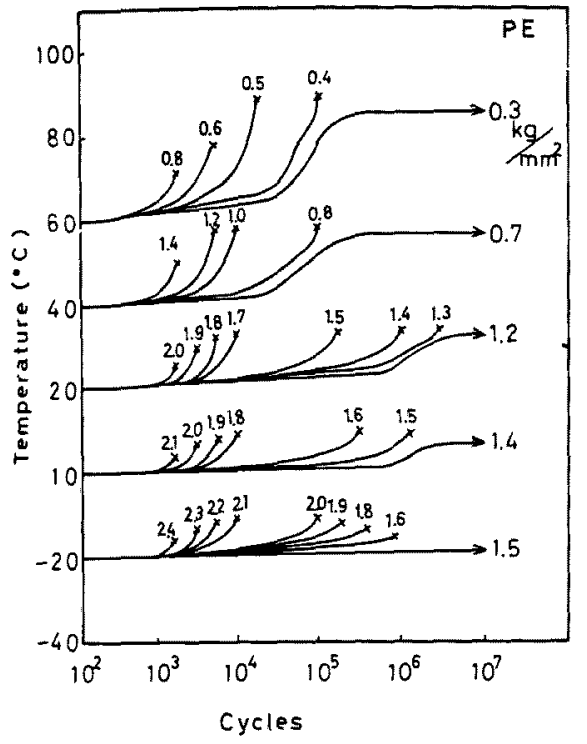

Fig. 10 Rise of surface temperature by fatigue at various temperatures for $\mathrm{PE}$.

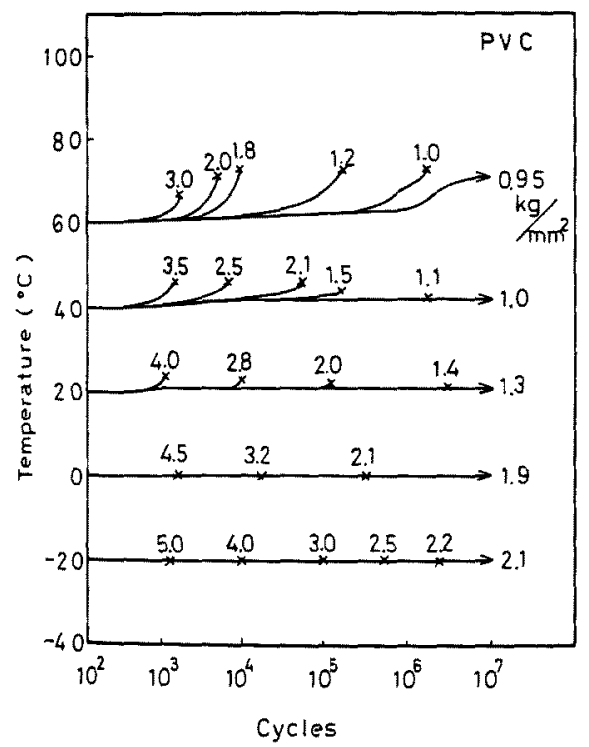

Fig. 11 Rise of surface temperature by fatigue at various temperatures for PVC.

す。また温度上昇幅は 0 C 20で極大となる傾向を示

す。图10はPEについての結果であり $0^{\circ} \mathrm{C} \sim 60^{\circ} \mathrm{C}$ では PMMA 上同様汇ある一定温度に到達すると疲労破壊す るのに対し，-20゚Cではあるサイクル数までは一定温度

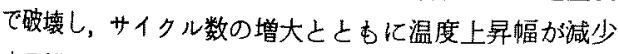
する傎向を示す。図11はPVCについての結果であり。 60 Cではある一定温度に到達すると疲労破塄が起り，

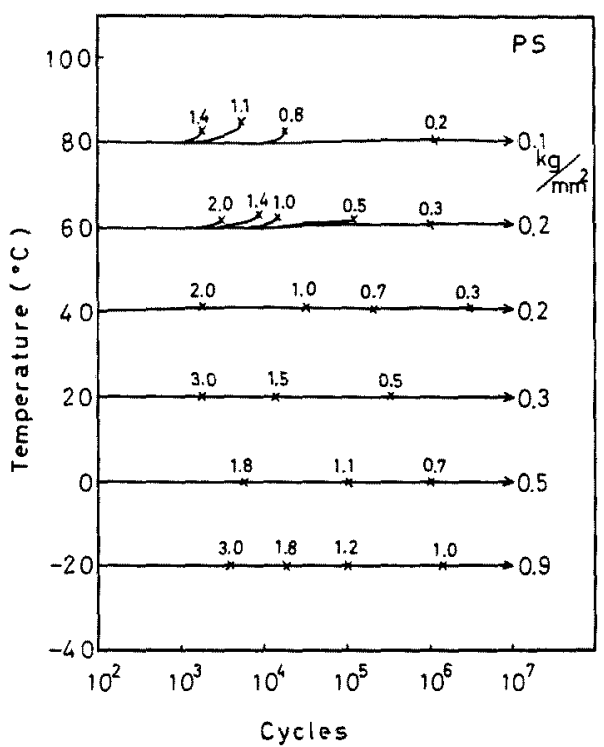

Fig. 12 Rise of surface temperature by fatigue at various temperatures for PS.

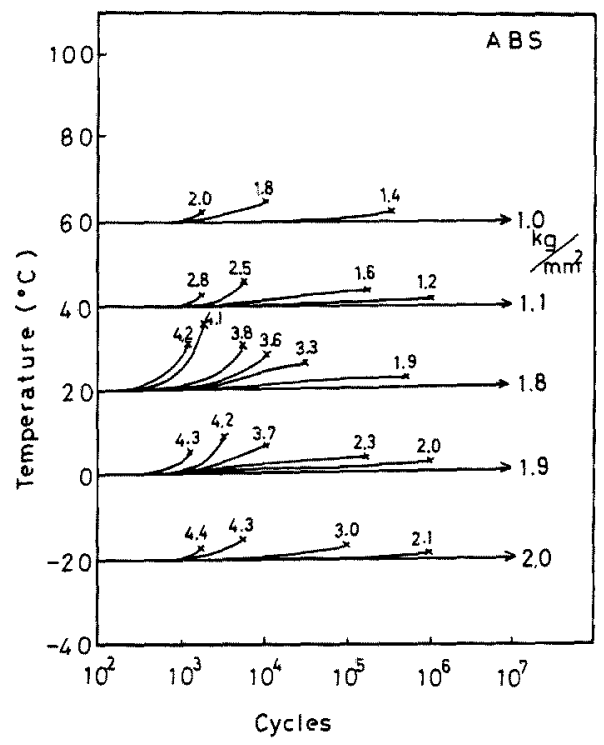

Fig. 13 Rise of surface temperature by fatigue at various temperatures for $\mathrm{ABS}$.

$40^{\circ} \mathrm{C}$ ではあるサイクル数までは一定温度に到達すると疲 学破壊し，サイクル数の增大としもに温度上昇幅が小さ い上とろで疲労破壊する傾向を示す。20゚ではサイクル 数の増大にしたがい疲学破壊における温度上昇幅が減少

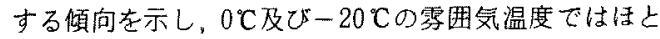
んど温度上昇が生じなくなる。图12はPSについての結

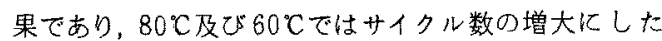




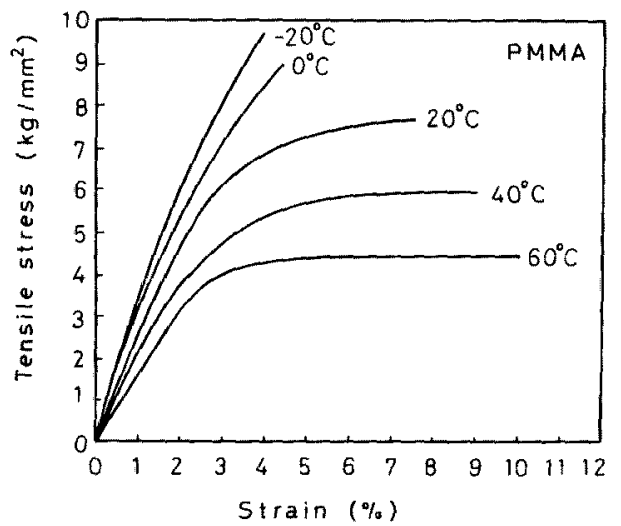

Fig. 14 S-S curves of PMMA at various temperatures.

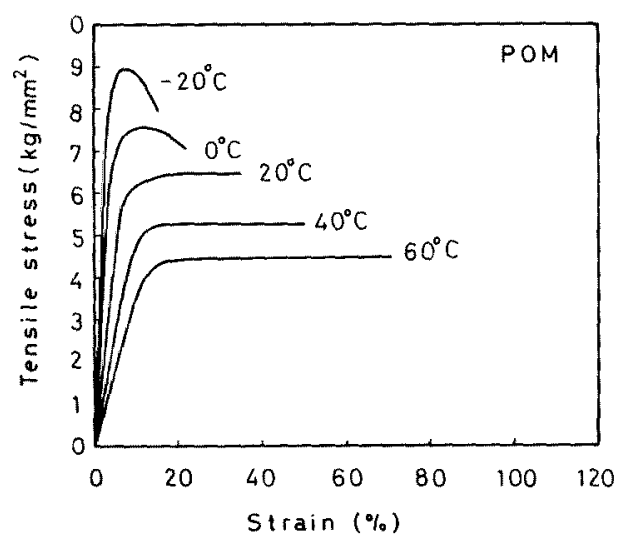

Fig. $15 \mathrm{~S}-\mathrm{S}$ curves of POM at various temperatures.

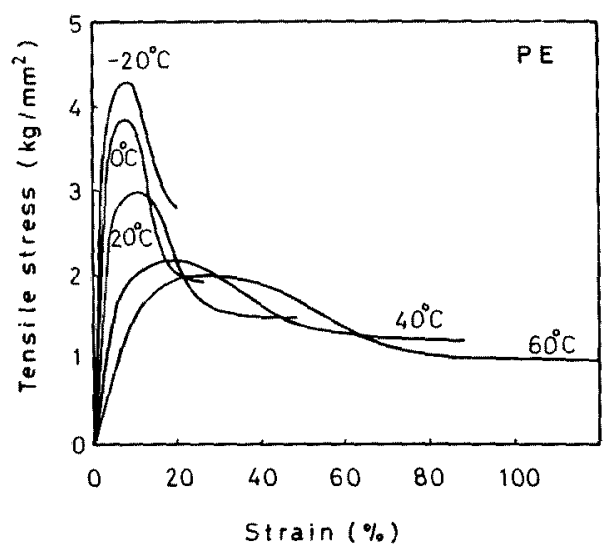

Fig. $16 \mathrm{~S}-\mathrm{S}$ curves of $\mathrm{PE}$ at various temperatures.

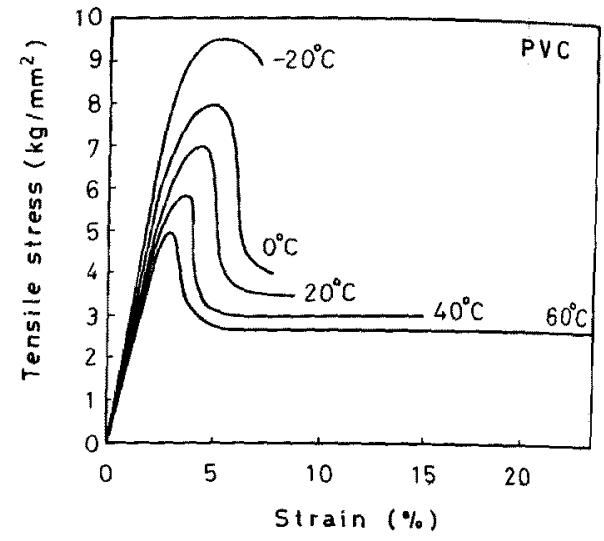

Fig. 17 S-S curves of PVC at various temperatures.

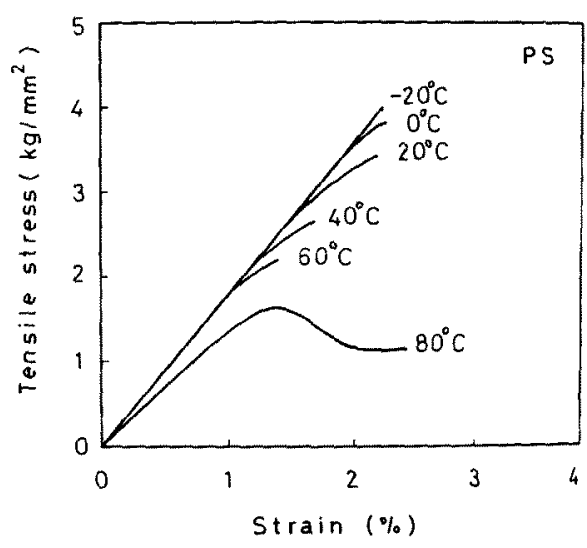

Fig. 18 S-S curves of PS at various temperatures.

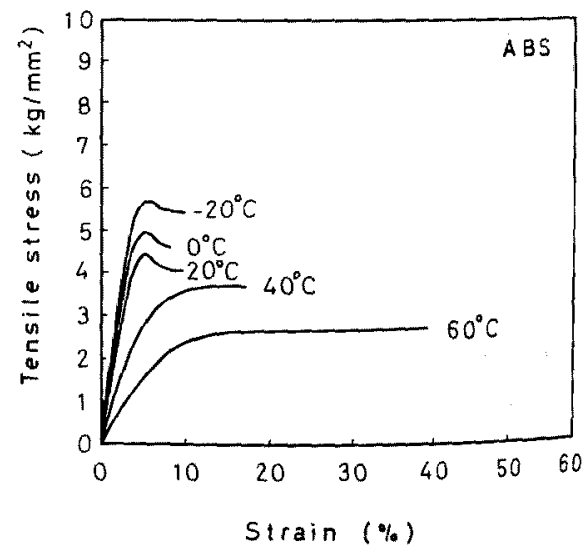

Fig. 19 S-S curves of $A B S$ at various temperatures. 
がい温度上昇幅が減少する㑯向を示し， $40^{\circ} \mathrm{C} \sim-20^{\circ} \mathrm{Cで}$ は活とんと温度上昇を生じない。图13はABSについて の結果であり， $-20 \mathrm{C} \sim 60$ Cにおいて，サイクル数の增 大にしたがい温度上昇幅が減少しているととを示す。ま た 20 C 付近に温度上昇幅の極大があるととを示してい る。

\subsection{S-S 曲線に及ぼす温度の影響}

上述の結果は，温度上昇のタイプが S-N曲線のタイ プに密接に関連していることを示崚しているが，さらに 温度上昇の幅が材料の機械的性質上関連しているととが 示畯されるので，引張試験による引張応力ーひずみ曲線 (S-S曲線)の温度による变化の傾向を検討した。図 14 ～19に各試料の温度によるS-S曲線の変化の傾向を示 した。因 14 はPMMAのS一S曲楾の温度による变化を

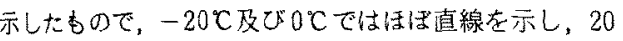
て〜60Cでは，3\%程度で降伏しひずみが増大している。 因15はPOMのS-S曲線を示しており，一20 C及ご0 Cで住降伏後，断面皘の急激な変化に上り応力が低下し ているが，20C〜60兄でははば均一延伸となっている。 図16はPEの結果であり，全ての温度において降伏後応 力の減少を生しており，断面皘の急激な変化をとむなっ ている。図17はPVCの結果であり，PEと同様に全て の温度において降代後断面積の急激な変化をとあなって いる。图18はPSの結果であり，-20C〜60 Cでは 伊直線的な変化を示している。図19はABSの結果であ り，-20C〜20Cまでは断面積の急激な变化をともな

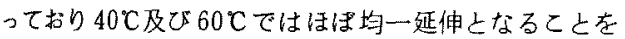
示している。

\section{4. 考察}

$\mathrm{S}-\mathrm{N}$ 曲線の転移現象については，多くの研究で指摘

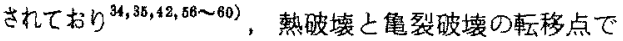
あると説明している 可塑性高分子材料の疲労強度の温度に上る变化を采統的 亿考察するために温度上昇の幅の変化，温度上昇の夕1 プ、S-N曲線のタイプ及びS-S曲楾のタイプをモデ 儿的に分類して各材料及び温度についてそれぞれ比較検 部した。

\section{1 温度上昇幅の変化の分類}

波学試験片の表面温度上昇の幅の変化は，結果加ら図 20 亿示すよう試験温度に対して極大示すことが明 ら加なった。この極大温度は，Ferry ${ }^{411}$ 亿よれば損 失コンプライアンスと繰り返し応力振幅の大きさのかね あいによるあの上考えられる。その極大付近の温度を B とし，温庭加高くなるに従い温度上昇幅か增大する領域 をA，逆化温度が高くなるに従い温度上昇䒇が減少する

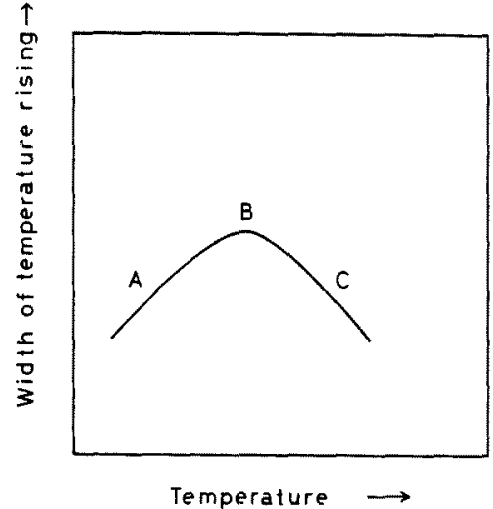

Fig. 20 Relation between temperature and change of width of temperature rising.

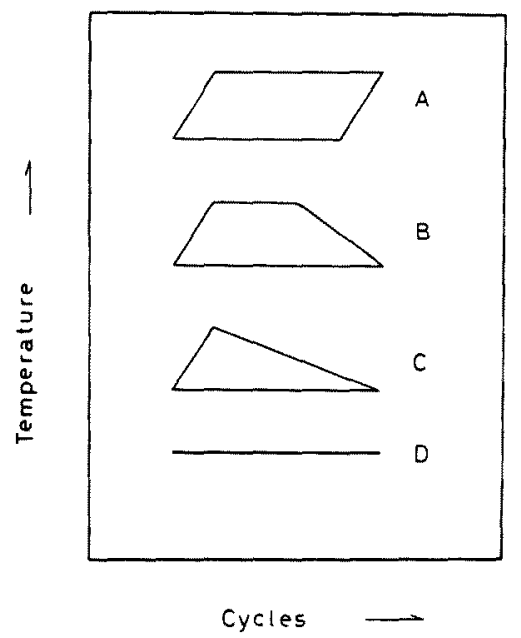

Fig. 21 Models for type of temperature rising.

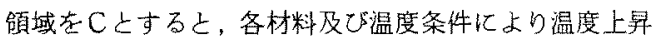
䒇の変化の分類ができる。

\section{2 温度上昇のタイプの分類}

瘏労試験片の表面温度の上昇の瘦労破壊サイクル数に 対する変化の夕イブを結果から尔類してモデル的に示す

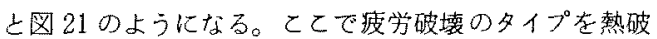

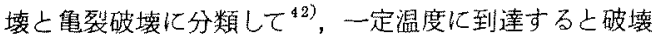
するタイプを熱破㘄タイプ，温度上昇によらず破壊する タイプを琵裂皮壊タイプと呼ぶ。Aは熱破罗タイプで試 験片表面か一定温度に到達したら破缺することを示して いる。Bはサイクル数が小さいときは一定温度に到達後 破壊し，サイクル数が大きくなると温度上舁によらず破

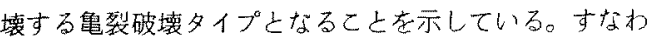
ち熱破壊上俥裂破壊の混合タイプである。Cはサイクル 数の増大にしたがい温度の上昇幅が減少するこ上を示し 
ている。すなわち温度上昇はみられるが，破壊は温度上 年によらない䖽破壊タイプを示すbのである。Dは絽

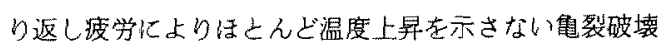
タイプを示すおのである。各材料及び温度条件により温 度上鼠のタイプが分類できる。

\section{$4.3 \mathrm{~S}-\mathrm{N}$ 曲線のタイプの分類}

温度変化に上る $\mathrm{S}-\mathrm{N}$ 曲線の变化の結果加的 22 亿示 すようにS-N曲楾のタイプはA，B及びCに行類でき る。この分類は上述の温度上昇のタイプの分類に対応し て分類できるあので，Aは熱破壊タイプ，Bは熱破壊と 亀裂破壊の混合タイプで転移点を有している。Cは龟裂 破壇の夕1プである。S-N曲線の転移琴象は，乙の上 うに温度上昇のタイプに基づく疲労破壊の機構の変化か ら説明できる ${ }^{42)}$ 。各試料及び温度条件による S-N曲線 のタイプが温度上年のタイプと対応させるととにより分 類できる。

\section{$4.4 \mathrm{~S}-\mathrm{S}$ 曲線のタイプの分類}

温度変化比よる各試料の S-S曲線の変化の結果加ら

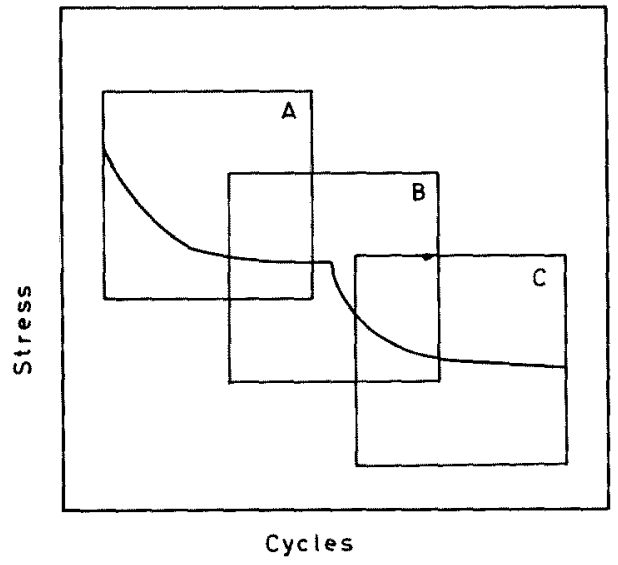

Fig. 22 Models for type of S-N curve.

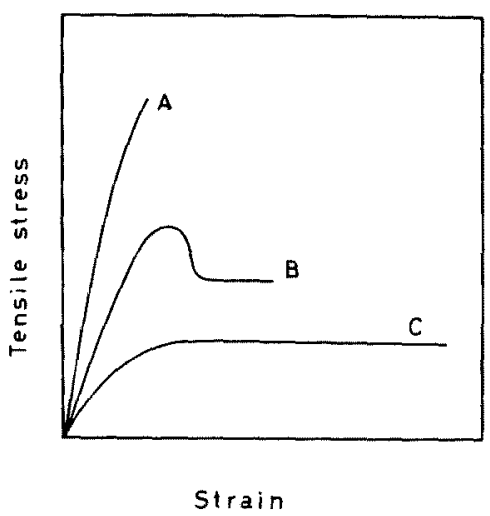

Fig. 23 Models for type of S-S curve.
四23に示すようにSーS曲線定分類するとよができる。 とれは損失コンプライアンスと応力の関係すなわち温度 上显幅に関係するちのである。Aは降伏点を示さず直線 的に変化するタイプ，Bは急激な断面皘変化をともなっ て隆伏点以後に応力が低下するタイプ，Cは降伏点以後 ほぼ均一延伸して伸度が大きくなるタイプである。各試 料及び温度条件により S-S曲線のタイプが分類できる。

\section{5 各材料及ひ温度条件に上る各分類の比較}

以上の四つの分類法により各材料及し温度条件に対し て分類を行った結果を表 1 に示す。温度が亳くなるに站

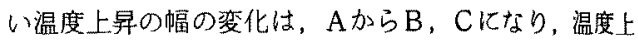
昇のタイプはD加らC， B，AKなり， $\mathrm{S}-\mathrm{S}$ 曲線の夕 イプはAからB，Cになり，S-N曲線のタイプはC加 らB，Aになる。温度上昇のタイプのC及び Dを $\mathrm{S}-\mathrm{N}$ 曲線の C と対応させると, 温度上䄯のタイプと $\mathrm{S}-\mathrm{N}$ 曲 線のタイプは全く一致するととになる。PMMA峈温 度よもAタイプで熱破壊型である。POMはー20兄及ひ O゚CにおいてはBタイプであり $\mathrm{S}-\mathrm{N}$ 曲線に転移点を有し ており，熱破壊上龟裂破壊の搌合型である。20 C 60 C 㧊いてはAタイプで熱破壊型である。PEはー20Сにおい てはBタイプで混合型であり， $0^{\circ} \mathrm{C} \sim 60^{\circ} \mathrm{C}$ では $\mathrm{A} タ$ イ゚で 熱破壊型である。PVCはー20〜20Cにおいては，度温 上昇 $\mathrm{D}, \mathrm{C} タ$ タプであり， $\mathrm{S}-\mathrm{N}$ 曲線 $\mathrm{C} タ$ タプで笠破 壊型である。40ではBタイプで混合型であり，60Cで はAタイプで熱破壊型である。PSは温度上昇でD，C タイプであり $\mathrm{S}-\mathrm{N}$ 曲線でCタイプの免裂破填型である。 ABSはCタイブで龟裂破壊型である。また温度上帠の 幅の変化とSーS曲線のタイプには密接な関係があり， $\mathrm{S}-\mathrm{S}$ 曲線がBまたは Aから $\mathrm{C}$ タイプに変換する付近で。 温度上昇の幅が極大となるBを示す。瑾境温度の変化们 対してS-S曲線のタイプが变化せず，ずっとBまたは Aの場合には，温度幅の変化もずっとAのままで温度か 高くなるに従い温度上昇の幅加增大する。本研究に拀い ては，PE，PVC及びPSがこのタイプであるが、Zilvar は6ナイロンについて温度が高い程，温度上昇輻が大き くなることを示しており，との結果あAの領域であった と思われる。

\section{6 温度による疲労強度の変化}

各材料の疲学強度に及ぼす温度の影䍌の結果及ひ上述 までの結果加ら，各材料の温度に対す石疲労強度は、㘡 24 亿示すような一本の曲線になるすの上思われる。各 材料によって温度による疲労強度の值は異なるが、 -20 Cから $600^{\circ} \mathrm{C}$ 变化は各材料によって一本の曲楾の中の一 部分であり，温度領域をひろげれば傾向として類似のる のになると考克られる。各材料については，図70結果 加ら各長方形で囲まれた温度領域がー20〜60Cの籍成の 
Table 1 Types of rise of surface temperature, $\mathrm{S}-\mathrm{S}$ curve and $\mathrm{S}-\mathrm{N}$ curve of thermoplastic polymers at various temperatures.

\begin{tabular}{|c|c|c|c|c|c|}
\hline material & $\begin{array}{l}\text { temperature } \\
\left({ }^{\circ} \mathrm{C}\right)\end{array}$ & $\begin{array}{l}\text { Change of width } \\
\text { of temperature } \\
\text { rising }\end{array}$ & $\begin{array}{l}\text { type of } \\
\text { temperature } \\
\text { rising }\end{array}$ & $\begin{array}{l}\text { type of } \\
\text { S-S curve }\end{array}$ & $\begin{array}{l}\text { type of } \\
S-N \text { curve }\end{array}$ \\
\hline \multirow{5}{*}{ PMMA } & -20 & $A$ & $A$ & $A$ & $\bar{A}$ \\
\hline & 0 & A & A & $A$ & A \\
\hline & 20 & $B$ & A & C & A \\
\hline & 40 & C & A & C & A \\
\hline & 60 & C & A & C & A \\
\hline \multirow{5}{*}{ POM } & -20 & $\Delta$ & B & B & $B$ \\
\hline & 0 & $B$ & B & $B$ & $B$ \\
\hline & 20 & C & $\bar{A}$ & $c$ & $\bar{A}$ \\
\hline & 40 & C & A & C & A \\
\hline & 60 & C & $\bar{A}$ & C & A \\
\hline \multirow{5}{*}{$P E$} & -20 & A & B & 8 & $B$ \\
\hline & 0 & A & A & 8 & $A$ \\
\hline & 20 & A & A & B & $A$ \\
\hline & 40 & A & A & $B$ & A \\
\hline & 60 & A & A & $B$ & A \\
\hline \multirow{5}{*}{$P \vee C$} & -20 & A & D & $\mathrm{B}$ & $C$ \\
\hline & 0 & $\bar{A}$ & D & $B$ & C \\
\hline & 20 & A & $C$ & $\bar{B}$ & C \\
\hline & 40 & $\Delta$ & B & $B$ & $B$ \\
\hline & 60 & A & $A$ & $\bar{B}$ & A \\
\hline \multirow{5}{*}{$P S$} & -20 & $\bar{A}$ & D & $A$ & $\mathrm{C}$ \\
\hline & 0 & $\bar{A}$ & $D$ & $A$ & C \\
\hline & 20 & $\Delta$ & D & $A$ & $\mathrm{C}$ \\
\hline & 40 & $A$ & D & $\Delta$ & $C$ \\
\hline & 60 & A & C & A & C \\
\hline \multirow{5}{*}{ A B S } & -20 & A & C & 8 & $C$ \\
\hline & 0 & $B$ & C & $B$ & $C$ \\
\hline & 20 & $B$ & C & $B$ & C \\
\hline & 40 & $\mathrm{C}$ & C & $c$ & C \\
\hline & 60 & $\mathrm{C}$ & C & $c$ & C \\
\hline
\end{tabular}

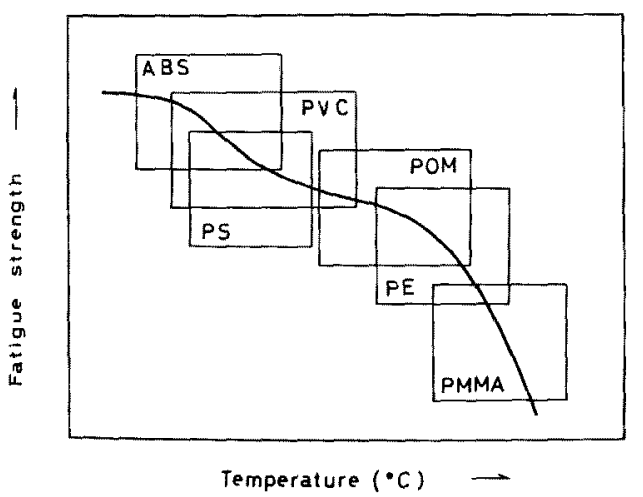

Fig. 24 Change of fatigue strength by temperature for thermoplastic polymers.

疲学強度の変化をあらわしている。すなわち同じー $20{ }^{\circ} \mathrm{C}$ 〜 60年の温度領域です，例えばABS としては他の材料 に比へて最击低温領域で疲労試験が行なわれたととにな り，PMMAは最あ高温領域で疲学試験が行なわれたて とになる。疲労強度一温度曲線には低温倒之高温側にシ ョルダーがある。高温側のショルダー付近に熱破羁之䉓 裂鮍填の軚移領域があり，ての領域を境として低温側は
龟裂破垻、高温側は熱破壊老す。

\section{5. 結言}

6 種類の汎用熱可塑性高分子材料の繰り返し届曲疲学 強度に及ばす温度の影響につて, 温度之疲労強度, $\mathrm{S}$ - $\mathrm{S}$ 曲線のタイプ、S-N曲線のタイプ, 温度上昇幅の変 化のタイプ及び盜度上昇のタイプの関係加ら検討した。

熱可塑性高分子材料の疲労強度は温度に対して一本の 曲線であら扣すとよができ，それはある転移温度を有し ている。転移温度在境にそ机上り低温側は疲学破罗が温 度上昇に上らない龟裂破壊を示し，高温側はヒステリシ 不損失に基つく温度上昇に上り，ある一定温度になった 上さ破壊を生ずる熱破壊を示す。 $-20^{\circ} \mathrm{C} \sim 60 \mathrm{C}$ の温度 領域では，ABS及びPSは亀裂破壊を示し，PVC， POM及びPEは熱破壊と龟裂破壊の両方を示L，PMMA は熱貱罗省す。PMMAの上うに熱破罗のみを示す条

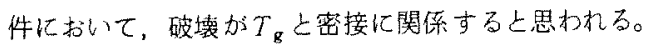

今後，各材料について温度領域党搪げて検討するとと により，さらに詳細な事実が明らかにされることが期待 できる。

〈付記〉本報告の一部は，第 7 回繊維連合研究発表 会(昭和 50 年 10 月大阪) にて発表したすのである。 


\section{文献}

1) J. F. Knott, "Fundamental of Fracture Mechanics", Wiley, New York (1973)

2) L. E. Nielsen, "Mechanical Properties of Polymers and Composites", Vol. 2, Marcel Dekker Inc., New York (1974)

3) C. B. Bucknall, "Toughened Plastics", Applied Science Publishers, London (1977)

4) R.W. Hertzberg and A. Manson, "Fatigue of Engineering Plastic", Academic Press, New York (1980)

5) G. Pitman and I. M. Ward, J. Mater. Sci., 15, $635(1980)$

6) C. B. Bucknall and W. W. Stevens, J. Mater. Sci, 15, $2950(1980)$

7) Y. Oikawa, J. Macromol. Sci. Phys., B19, 679 (1981)

8) C. M. Rimnac, J. A. Manson, R. W. Hertzberg, S. M. Webler, and M. D. Skibo, J. Macromol. Sci. Phys., B19, 351 (1981)

9) D. J. Woan, M. Habibullah, and J. A. Sauer, Polymer, 22, 699 (1981)

10) R. Vinet, R. Connolly, and R. Gauvin, Polym. Eng. Sci., 21, 1203 (1981)

11) C. C. Chen, N. Chheda, and J. A. Sauer, J. Macromol. Sci. Phys., B19, 565 (1981)

12) J. A. Sauer, M. Habibullah, and C. C. Chen, J. Appl. Phys., 52, 5970 (1981)

13) R. W. Nunes, J. R. Martin and J. F. Johnson, Polym. Eng. Sci., 22, 205 (1982)

14) M. T. Takemori and D. S. Matsumoto, $J$. Polym. Sci. Phys., 20, 2027 (1982)

15) M. T. Takemori, Polym. Eng. Sci., 22, 937 (1982)

16) A. Chudnovsky and A. Moet, Polym. Eng. Sci., 22, 922 (1982)

17) E. Foden, D. R. Morrow, and J. A. Sauer, J. Appl. Polym. Sci., 16, 519 (1972)

18) J. G. Williams, "Stress Analysis of Polymers", 2nd edn, J. Wiley and Sons, New York $\langle 1980\rangle$

19) M. T. Hahn, R. W. Hertzberg, J. A. Manson, R. W. Lang, and P. E. Bretz, Polymer, 23, $1675(1982)$

20) C. C. Chen, D. R. Morrow, and J. A. Sauer, Polym. Eng. Sci., 22, 451 (1982)

21) J. A. Sauer and C. C. Chen, Polym. Eng. Sci, 24, 786 (1984)

22) R. W. Lang, M. T. Hahn, R. W. Hertzberg and J. A. Manson, J. Mater. Sci. letters, 3, 224 (1984)

23) J. A. Sauer and C. C. Chen, Adv. in Polym. Sci., 52/53, 170 (1983)

24) T. A. Morelli, and M. T. Takemori, J. Mater. Sci., 19, 385 (1984)

25) R. Connolly, R. Gauvin, and J. P. Chalifoux,
Polym. Eng. Sci., 25, 548 (1985)

26) M. G. Schinker, L. Könczöl, and W. Döll, Colloid \& Polymer Sci., 262, 230 (1984)

27) C. M. Rimnac, R.W. Hertzberg, and J.A. Manson, J. Mater. Sci. letters, 2, 325 (1983)

28) M. Kitagawa, H. Kajiwara, H. Kanzaki, and T. Zhang, J. Mater. Sci., 20, 1945 (1985)

29) D. S. Matsumoto and S. K. Gifford, J. Mater, Sci. 20, 4610 (1985)

30) T. A. Morelli, and M. T. Takemori, J. Mater. Sci., 18, 1836 (1983)

31) A. M. Serrano, G. E. Welsch and R. Gibala, Polym. Eng. Sci., 22, 946 (1985)

32) E.P. Tam and G.C. Martin, J. Macromol. Sci. Phys., B23, 415 (1984 85)

33) B. J. Lazan, and A. Yorgiadis, ASTM, STP24, 66 (1944)

34) S. Shimamura, and H. Maki, Proc. JCTM 5 , 136 (1961)

35) S. Shimamura, and H. Maki, Proc. JCTM, 6, 6 (1962)

36) S. B. Ratner, and V. I. Korobov, Mekh. Polim., 1, 93 (1965)

37) M. N. Riddell, G. P. Koo and J. L. O'Toole, Polym. Eng. Sci., 6, 363 (1966)

38) G. P. Koo, M. N. Riddell, and J. L. O'Toole, Polym. Eng. Sci., 7, 182 (1967)

39) L. C. Cessna, J. A. Levens, and J. B. Thomson, Polym. Eng. Sci, 9, 339 (1969)

40) A. X. Schmidt and C. A. Marlies, "Principle of High-Polymer Theory and Practice" p578, McGraw-Hill, New York (1948)

41) J. D. Ferry, "Viscoelastic Properties of Polymers", Wiley, New York (1961)

42) R. J. Crawford, and P. P. Benham, Polymer, 16, 908 (1975)

43) L. J. Broutman, and S. K. Gaggar, Inst. J. Poly. Mater., 1, 295 (1972)

44) A. V. Stinskas and S. B. Ratner, Sov. Plast., 49 (1962)

$45)$ R. W. Hertzberg, J. A. Manson, and M. D. Skibo, Polymer, 19, 358 (1978)

46) 大石不二夫, 材料, 7, 826(1968)

47) T. R. Tauchert, and S.M. Afzal, J. Appl. Phys., 38, 4568 (1967)

48) K. Oberbach, Kunstoffe, 63, 35 (1973)

49) M. Higuchi, and Y. Imai, J. Appl. Polym. Sci. 14, 2377 (1970)

50) 大石不二夫，材料，17，1016(1968)

51) S. Wintergerest, Kunstoffe, 50, 277 (1960)

52) P. P. Benham, and V.I. Korobov, Mekh. Polim., 1, 93 (1965)

53) A. V. Strinkas, N. I. Antropava, S. B. Ratnet, A. V. Samokhvalov, and A. V. Sharova, Mekh. Polim., 1, 118 (1965)

54) V. Zilvar, J. Macromol. Sci. Phys., B5, 273 (1971) 
55) V. Zilvar, Plas. Polym., 39, 328 (1971)

56) 堀幸夫, 機械の研究, 11, 675(1959)

57)场幸夫，高分子，10，606（1961）

58) 黒田寿記，石橋 徽，材料試験，10，485(1961)

59) 黑田毒記, 谷口 登, 材料試験, 11，504 (1962)

60) 黑田寿記，小牧和夫，材料，14，172(1965)

61) J. R. Martin and J. F. Johnson, J. Appl, Polym. Sci., 18, 3227 (1974)

62) J. A. Sauer, E. Foden, and D. R. Morrow, SPE ANTEC Tech. Pap., 22, 107 (1976)

63) S. L. Kim, M. D. Skibo, J. A. Manson and R. W. Hertzberg, Polym. Eng. Sci., 17, 194 (1977)

64) E. Foden, J. A. Sauer and D. R. Morrow, J. Appl. Polym. Sci., 16, 519 (1972)

65) A. N. Gent and A. G. Thomas, J. Polym. Sci. Part A-2, 10, 571 (1972)

66) R. P. Kambour, J. Polym. Sci., Part D. 7, 1 (1973)

67) J. F. Fellers, and B. F. Kee, J. Appl. Polym. Sci., 18, 2355 (1974)

68) F. Ohishi, S. Nakamura, D. Kogama, K. Minabe, Y. Fujisawa and Y. Tsuruga, J. Appl. Polym. Sci., 20, 79 (1976)

69) S. Warty, J. A. Sauer and A. Charlesky, Eur. Polym. J., 15, 445 (1979)

70) J.A. Sauer, E. Foden and D. R. Morrow, Polym. Eng. Sci., 17, 246 (1977)

71) S. K. Bhateja, J. K. Reike and E. H. Andrews, J. Mater. Sci., 14, 2103 (1979)

72) S. L. Kim, M. D. Skibo, J. A. Manson, R. W. Hertzberg and J. Janiszewski, Polym. Eng. Sci. 18, 1093 (1978)

73) J.H. Dillon, "Advances in Colloid Science", Vol. 3, p219, H. Mark, E. J.W. Verwey, Ed.,
Interscience, New York (1950)

74) 大石不二夫, 材料，17，44 (1968)

75) P. Beadmore and S. Rabinowitz, Appl. Polym. Symp., 24, 25 (1974)

76) S. Arad, J. C. Radon, and L. E. Culver, Polym. Eng. Sci., 12, 193 (1972)

77) S. Arad, J. C. Radon, and L. E. Culver, J. Mech. Eng. Sci., 13, 75 (1971)

78) W. J. Plumbridge, J. Mater. Sci., 7, 939 (1972)

79) J.G. Williams, J. Mater. Sci., 12, 2525 (1977)

80) G. C. Martin and W. W. Gerberich, J. Mater. Sci., 11, 231 (1976)

81) R.W. Hertzberg, H. Nordberg, and J. A. Manson, J. Mater. Sci., 5, 521 (1970)

82) J. C. Radon and L. E. Culver, Polym. Eng. Sci., 15, 500 (1975)

83) S. Arad, J. C. Radon, and L. E. Culver, J. Mech. Eng. Sci., 13, 2 (1971)

84) S. Arad, J.C. Radon, and L. E. Culver, J. Mech. Eng. Sci., 14, 328 (1972)

85) N. H. Watts and D. J. Burns, Polym. Eng. Sci., 7, $90(1967)$

86) T. Kurobe and H. Wakashima, in Proceeding of the 15th Japan Congress on Materials Research, Society of Materials Science, Kyoto, Japan, p137 (1972)

87) J. C. Radon, P. Chauhan, and L. E. Culver, Colloid Polym. Sci., 254, 382 (1976)

88) J.C. Radon, Polym. Eng. Sci., 12, 425 (1972)

89) J.C. Radon and L. E. Culver, Polym. Eng. Sci. 15, 507 (1975)

90) S. B. Ratner, and N. I. Barash, Mekh. Polim., 1,124 (1965) 